\title{
FENOMENA ALIRAN TAYLOR COUETTE POISEUILLE DENGAN ALIRAN AKSIAL-RADIAL DI DALAM SILINDER KONSENTRIS
}

\author{
Sarip \\ Jurusan Teknik Mesin, Sekolah Tinggi Teknologi Ronggolawe Cepu \\ E-mail: hidayatullohsarip566@gmail.com
}

Masuk: 27-08-2020, revisi: 25-04-2021, diterima untuk diterbitkan: 30-04-2021

\begin{abstract}
ABSTRAK
Proses penyaringan yang menggunakan teknologi membran merupakan modifikasi dari aliran Taylor-Couette, yaitu aliran diantara dua buah silinder konsentris yang berputar dengan aliran aksial dan radial serta memanfaatkan vortex yang terjadi pada aliran Taylor-Couette yang dapat meningkatkan efisiensi membran. Tujuan penelitian dilakukan untuk mengetahui fenomena aliran Taylor Couette Poiseuille dengan aliran aksial-radial di dalam silinder konsentris. Penelitian menggunakan seksi uji berupa dua silinder konsentris, yang mana silinder bagian dalam berputar sebagai membran sedangkan silinder luar diam dengan tinggi $500 \mathrm{~mm}$, perbandingan radius 0,72; perbandingan aspek 40 dan celah silinder 12,5 mm. Putaran silinder bagian dalam diatur menggunakan inverter untuk mendapatkan putaran yang diharapkan. Fenomena pengamatan pola aliran dilakukan dengan menggunakan camera digital pada putaran silinder bagian dalam yang berbeda-beda. Hasil penelitian menunjukkan bahwa perubahan putaran silinder bagian dalam mempengaruhi pola aliran Taylor-Couette yang terbentuk secara berjenjang yaitu Couette laminar, Taylor-vortex yang ditandai dengan munculnya vortex yang saling berpasangan, berlawanan arah yang terjadi di sepanjang aliran, wavy vortex dan vortex turbulant. Perubahan porousitas membran juga menunjukkan pengaruh fenomena aliran Taylor Couette Poiseuille dengan aliran aksial-radial yang semakin tinggi maka transisi terjadinya vortex terjadi pada bilangan Taylor yang lebih tinggi pula berarti stabilitas aliran Couette-Poiseuille meningkat.
\end{abstract}

Kata kunci : Aliran aksial-radial; Silinder konsentris; Fenomena aliran Taylor-Couette.

\begin{abstract}
The filtering process using membrane technology is a modification of Taylor-Couette flow, which is a flow between two concentric cylinders that rotates with axial and radial flow and utilizes the vortex that occurs in Taylor-Couette flow which can increase membrane efficiency. The purpose this study was to determine the phenomenon of the Taylor Couette Poiseuille flow with axial-radial flow in concentric cylinders. The study was usesd a test section in the form of two concentric cylinders, in which the inner cylinder rotates as a membrane while the outer cylinder is stationary with a height of $500 \mathrm{~mm}$, a radius ratio of 0.72; aspect ratio 40 and cylinder gap $12.5 \mathrm{~mm}$. The inner cylinder rotation is set using an inverter to get the expected rotation. The phenomenon of observing flow patterns is done by using digital cameras on different inner cylinder turns. The results showed that changes in the inner cylinder rotations affect the flow pattern of Taylor-Couette that is formed in stages, namely laminar Couette, Taylor-vortex which is characterized by the appearance of paired vortexes, opposite directions that occur along the flow, wavy vortex and turbulant vortex. Changes in membrane porousity also show the effect of Taylor Couette Poiseuille flow phenomena with axial-radial flow which is higher, the transition to vortex occurs at higher Taylor numbers also means that Couette-Poiseuille flow stability increased.
\end{abstract}

Keywords: axial-radial flow; Concentris cylinders; Taylor-Couette flow phenomenon. 


\section{PENDAHULUAN \\ Latar Belakang}

Kebutuhan air bersih di perkotaan bisa menjadi permasalahan ketika banyak bahan limbah industri maupun rumah tangga yang dapat mencemari sumber air bersih. Sementara populasi penduduk yang semakin besar juga membuat kebutuhan air bersih meningkat. Permasalahan ini akhirnya bisa melebar menjadi masalah kesehatan dan ekonomi pada masyarakat. Salah satu solusi alternatif dari permasalahan di atas adalah dengan mengupayakan rekayasa daur ulang air melalui proses penyaringan. Dengan penyaringan maka air yang sudah dipakai pada proses industri maupun rumah tangga menjadi bersih lagi dan bisa digunakan kembali. Proses penyaringan yang dapat diterapkan salah satunya adalah dengan menggunakan teknologi membran. Teknologi ini juga dipakai pada proses produksi air minum dengan prinsip Reverse Osmosis, yaitu dengan mengalirkan air pada celah di antara dua buah silinder konsentris dengan silinder bagian dalamnya membran.

Proses penyaringan di atas merupakan modifikasi dari aliran Taylor-Couette, yaitu aliran diantara dua buah silinder konsentris yang berputar. Leuptow (2004) telah meneliti tentang aliran Taylor-Couette dengan variasi penambahan aliran aksial dan radial dengan memanfaatkan vortex yang terjadi pada aliran Taylor-Couette untuk meningkatkan efisiensi filter. Pola aliran Couette laminar dalam sebuah sistem aliran Taylor-Couette, akan mengalami transisi ke pola aliran Taylor vortex jika putaran silinder bagian dalam dinaikkan sampai melampaui nilai tertentu. Pola aliran Taylor vortex ditandai dengan munculnya vortex yang saling berpasangan berlawanan arah secara teratur di sepanjang sistem aliran. Perubahan pola aliran pada sistem Taylor-Couette atas pengaruh putaran silinder digambarkan dengan cukup lengkap oleh Andereck dkk. (1986) melalui eksperimen yang memvisualisasikan aliran fluida di antara dua silinder konsentris yang berputar secara bebas antara satu dengan yang lainnya.

Leuptow dkk. (1992) berdasarkan hasil eksperimen aliran diantara dua buah silinder konsentris dengan perbandingan radius 0,848 dan perbandingan aspek 41 , berhasil menyusun peta pola aliran Couette-Poiseuille sebagai fungsi dari bilangan Reynolds aksial dan bilangan Taylor seperti pada gambar 1.

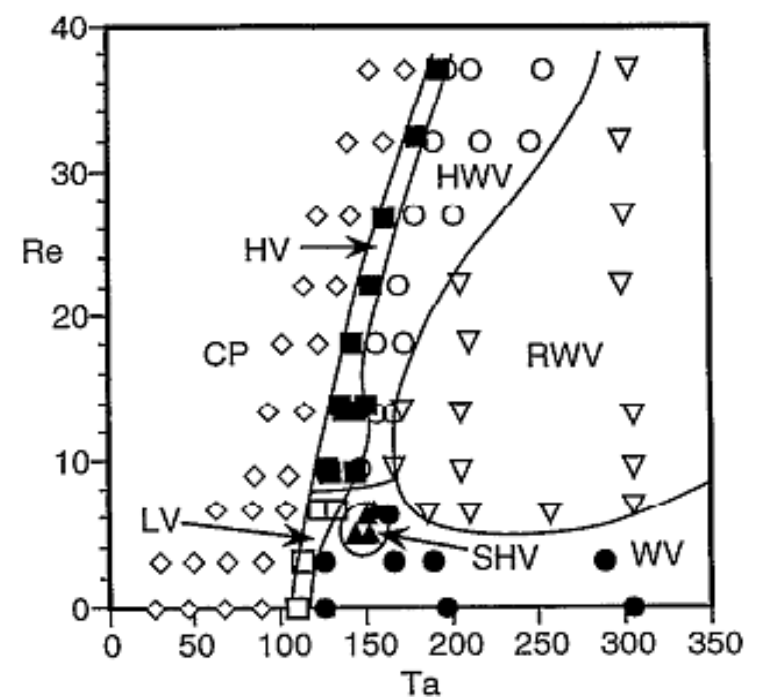

$\begin{array}{ll}\text { Keterangan: } & \\ \text { CP } & \text { Couette-Poiseuille flow } \\ \text { HV } & \text { Laminar helical vortices } \\ \text { HWV } & \text { Laminar helical wavy vortices } \\ \text { LV } & \text { Laminar vortices } \\ \text { MWV } & \text { Laminar modulated wavy vortices } \\ \text { RWV } & \text { Random laminar wavy vortices } \\ \text { SHV } & \text { Stationary helical vortices } \\ \text { TMW } & \text { Turbulent modulated wavy vortices } \\ \text { TRA } & \text { Transitional flow } \\ \text { TV } & \text { Turbulent vortices } \\ \text { TWV } & \text { Turbulent wavy vortices } \\ \text { WV } & \text { Laminar wavy vortices }\end{array}$

Gambar 1. Peta pola aliran Taylor-Couette-Poiseuille dengan silinder bagian dalam berputar sebagai fungsi dari bilangan Reynolds aksial dan bilangan Taylor

(Leuptow dkk., 1992) 
Pada aliran Couette-Poiseuille, aliran vortex terjadi pada bilangan Taylor yang lebih tinggi yang dapat meningkatkan stabilitas aliran. Adanya aliran aksial juga dapat menyebabkan munculnya bilangan Reynold aksial meningkat sehingga stabilitas aliran semakin baik. Aliran vortex yang semakin meningkat dapat meningkatkan gaya sentrifugal pada dinding filter yang dapat menyapu kotoran-kotoran yang menempel sehingga meningkatkan efisiensi.

Leuptow dan Min (1994) melanjutkan eksperimen dengan menggunakan silinder porous sebagai silinder bagian dalam yang berputar, sehingga selain aliran melingkar dan aliran aksial juga akan terjadi aliran pada arah radial. Pola aliran yang disusun Leuptow dan Min sebagai fungsi dari bilangan Reynolds aksial dan bilangan Taylor pada bilangan Reynolds radial 0,028 dan 0.051 dapat dilihat pada gambar $3 \mathrm{a}$ dan 3b. Terlihat jika bilangan Reynolds aliran radial semakin tinggi maka transisi terjadinya vortex terjadi pada bilangan Taylor yang lebih tinggi atau dengan kata lain stabilitas aliran Couette-Poiseuille akan meningkat. Perbandingan visualisasi bentuk pola aliran antara aliran Couette-Poiseuille tanpa dan dengan aliran radial dapat dilihat pada gambar $2 \mathrm{a}$ dan $2 \mathrm{~b}$

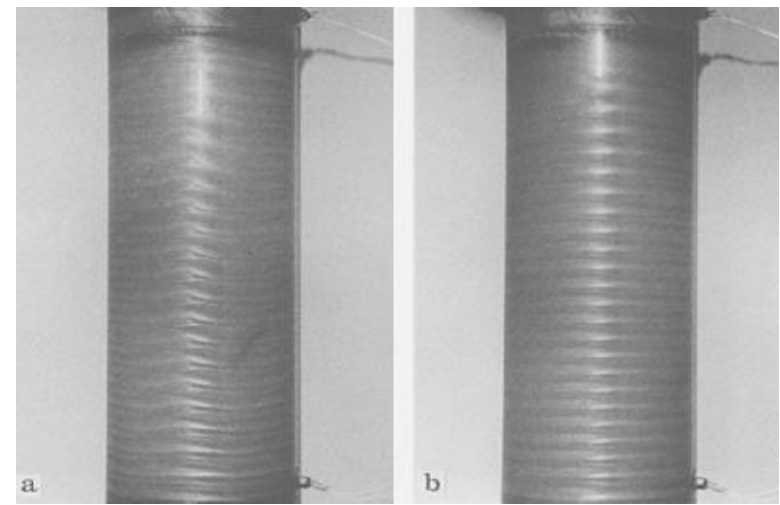

Gambar 2. Visualisasi perbandingan pola aliran, (a) tanpa adanya aliran radial (b) dengan adanya aliran radial (Leuptow dan Min, 1994)

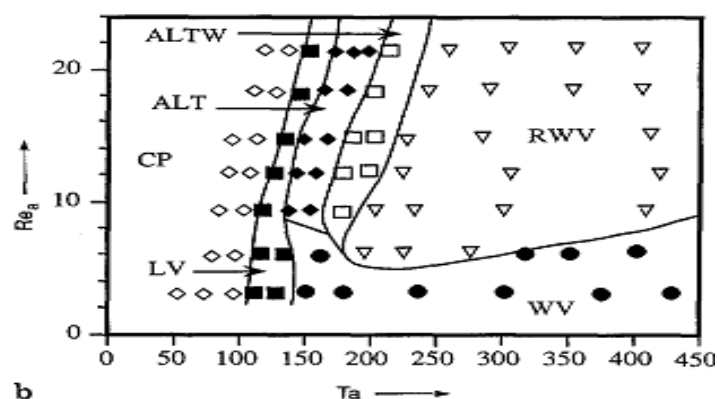

$\begin{array}{ll}\text { Keterangan: } \\ \text { ALT } & \text { Alternating helical vortices } \\ \text { ALTW } & \text { Alternating wavy helical vortices } \\ \text { CP } & \text { Couette-Poiseuille flow } \\ \text { HV } & \text { Laminar helical vortices } \\ \text { HWV } & \text { Laminar helical wavy vortices } \\ \text { LV } & \text { Laminar vortices } \\ \text { RWV } & \text { Random laminar wavy vortices } \\ \text { SHV } & \text { Stationary helical vortices } \\ \text { WV } & \text { Lamina wavy vortices }\end{array}$

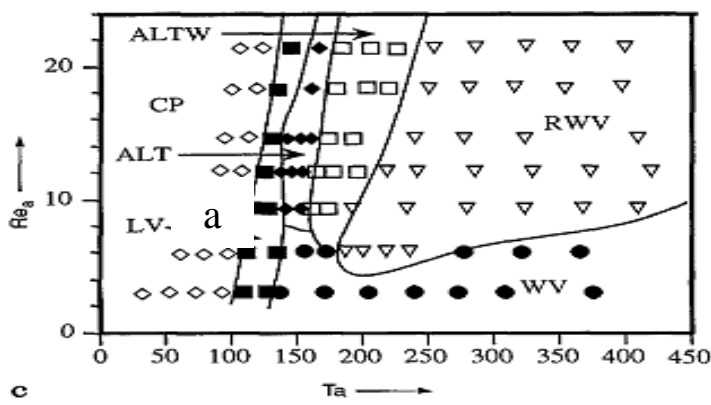

Gambar 3. Peta pola aliran Taylor-Couette-Poiseuille dengan silinder bagian dalam porous pada bilangan Reynolds radial (a) 0,028 (b) 0.051 (Leuptow dan Min, 1994). 


\section{Rumusan Masalah}

Bagaimana fenomena aliran Taylor-Couette Poiseuille dengan aliran aksia-radial di dalam silinder konsentris?

\section{METODE PENELITIAN}

\section{Bahan dan Skema Alat Penelitian}

Bahan

Bahan penelitian yang digunakan adalah air yang berfungsi sebagai fluida kerja dan serbuk aluminium yang berfungsi untuk memunculkan pola aliran. Air mempunyai massa jenis 1000 $\mathrm{kg} / \mathrm{m}^{3}$, viskositas dinamik: $1,002 \times 10^{-3} \mathrm{~N} . \mathrm{s} / \mathrm{m}^{2}$ dan viskositas kinematik: $1,004 \times 10^{-6} \mathrm{~m}^{2} / \mathrm{s}$. Sedangkan Serbuk aluminium mempunyai berat jenis: $2,707 \mathrm{~kg} / \mathrm{m}^{3}$ dengan ukuran 98 mikron.

\section{Skema Alat Penelitian}

Keterangan:
1. Inverter.
10. Influent.
17. Gate valve.
24. Gate valve.
2. Motor listrik.
11. Pressure gauge.
18. Flow meter keluar.
25. Gate valve.
3. Pully transmisi.
12. Gate valve.
4. Seksi uji.
13. Filtrat.
19. Flow meter masuk.
26. Gate valve.
5. Efluent.
14. Pressure
20. Gate valve.
6. Pressure transducer. transducer.
21. Flushing.
7. Gate valve.
15. Gate valve.
8. Gate valve.
9. Flushing
16. Gate valve.
22. Gate valve.
23. Globe valve.

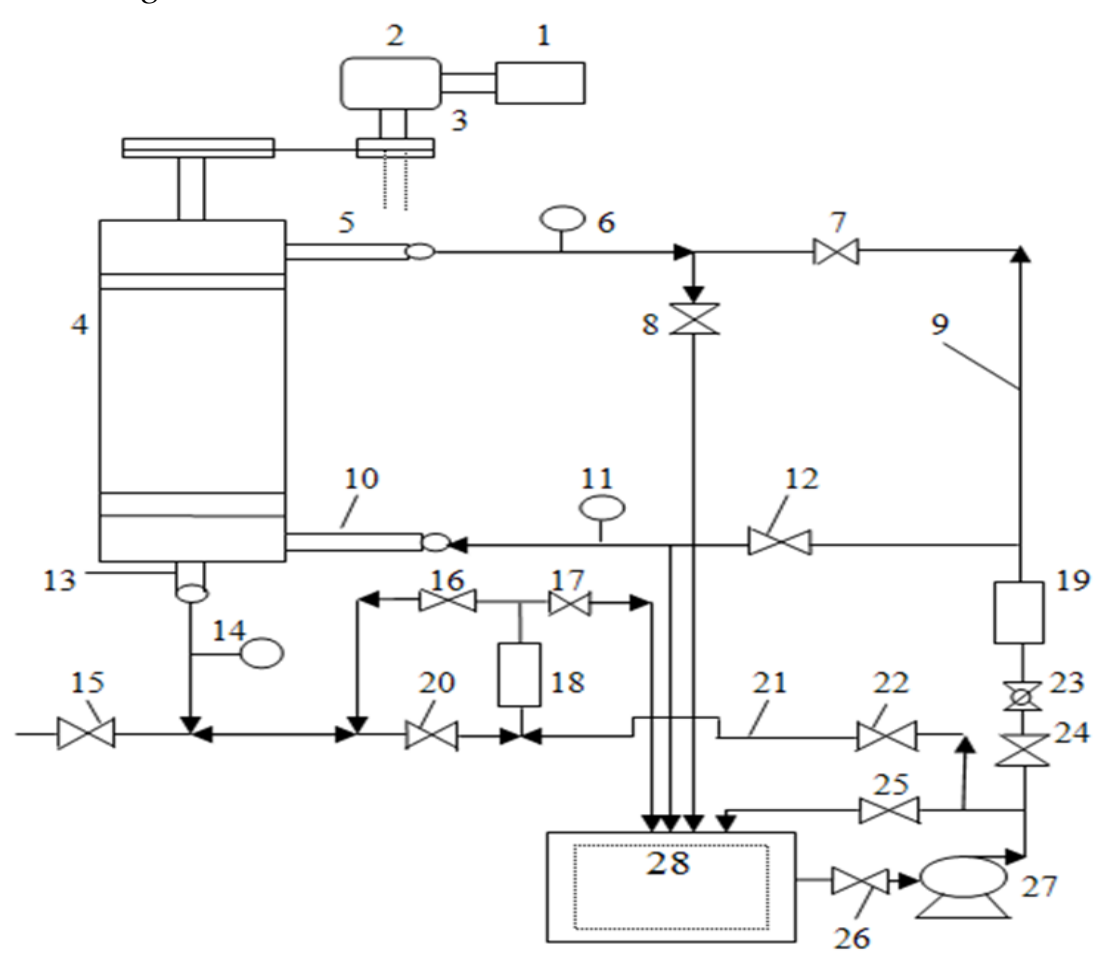

Gambar 4. Skema alat pengujian 
Silinder dalam diputar dengan motor listrik melalui transmisi sabuk-v yang diintegralkan pada sebuah inverter. Silinder dalam berfungsi sebagai filter untuk menyaring fluida yang sedang mengalir di dalam silinder konsentris. Fluida mengalir di antara silinder konsentris dengan arah aksial dan radial yang hasilnya dialirkan melalui bagian dalam filter tersebut. Pengukuran Torsi dan putaran silinder dilakukan melalui tiga tahap selama proses filtrasi. Proses filtrasi tahap satu dilakukan dengan porousitas filter 1 mikron, tahap kedua dengan porousitas filter 3 mikron dan tahap ketiga dengan porousitas filter 5 mikron. Porousitas filter digunakan untuk mengetahui pengaruh kecepatan putar silinder bagian dalam terhadap efektifitas filter yang dapat meningkatkan hasil filtrasi.

\section{HASIL DAN PEMBAHASAN}

\section{Aliran aksial-radial untuk silinder dalam satu mikron}

Penelitian aliran Taylor-Couette Poiseuille untuk silinder bagian dalam satu mikron dengan aliran aksial-radial menghasilkan fenomena pola aliran seperti tampak pada Gambar 5.

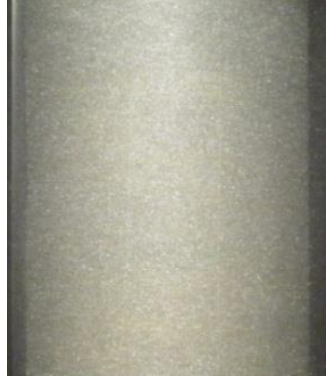

a

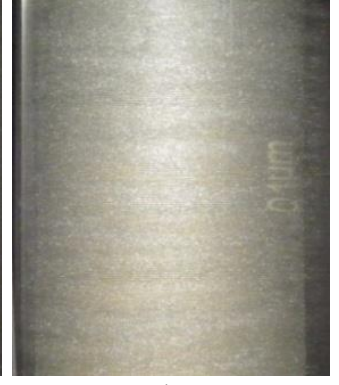

b

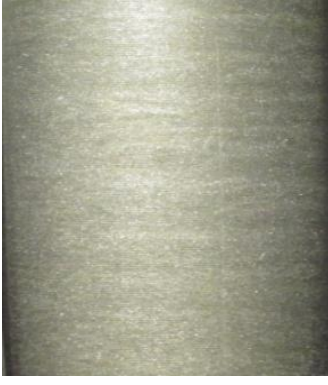

c

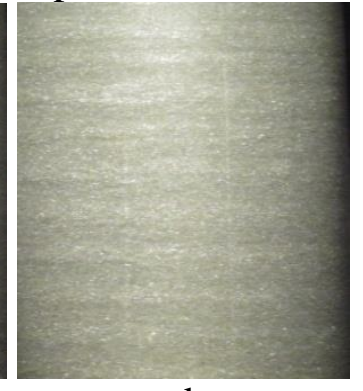

d

Gambar 5. Pola aliran Taylor-Couette dengan aliran aksial-radial untuk silinder dalam satu mikron pada $\mathrm{Re}_{\text {aksial }}=51,6$

a. Aliran couette laminer pada $\operatorname{Re}=99, \operatorname{Re} \operatorname{rad}=1,5$

b. Aliran Taylor-vortex pada $\mathrm{Re}=296, \mathrm{Re}_{\mathrm{rad}}=1,4$

c. Aliran wavy vortex pada $\operatorname{Re}=937, \operatorname{Re}_{\mathrm{rad}}=1,5$

d. Aliran vortex turbulen pada $\mathrm{Re}=1727, \mathrm{Re}_{\mathrm{rad}}=1,5$.

Dengan adanya aliran aksial-radial pola aliran Taylor-couette Poiseuille yang terbentuk mengalami perubahan dibanding dengan aliran Taylor-couette tanpa aliran aksial ditandai dengan transisi terjadinya vortex pada bilangan Reynolds yang tinggi atau pada bilangan Taylor yang tinggi pula artinya stabilitas aliran Taylor-couette Poiseuille juga meningkat.

Bila hasil visualisasi pola aliran tersebut dituangkan ke dalam sebuah gambar peta pola aliran maka posisinya seperti terlihat pada Gambar 6. 


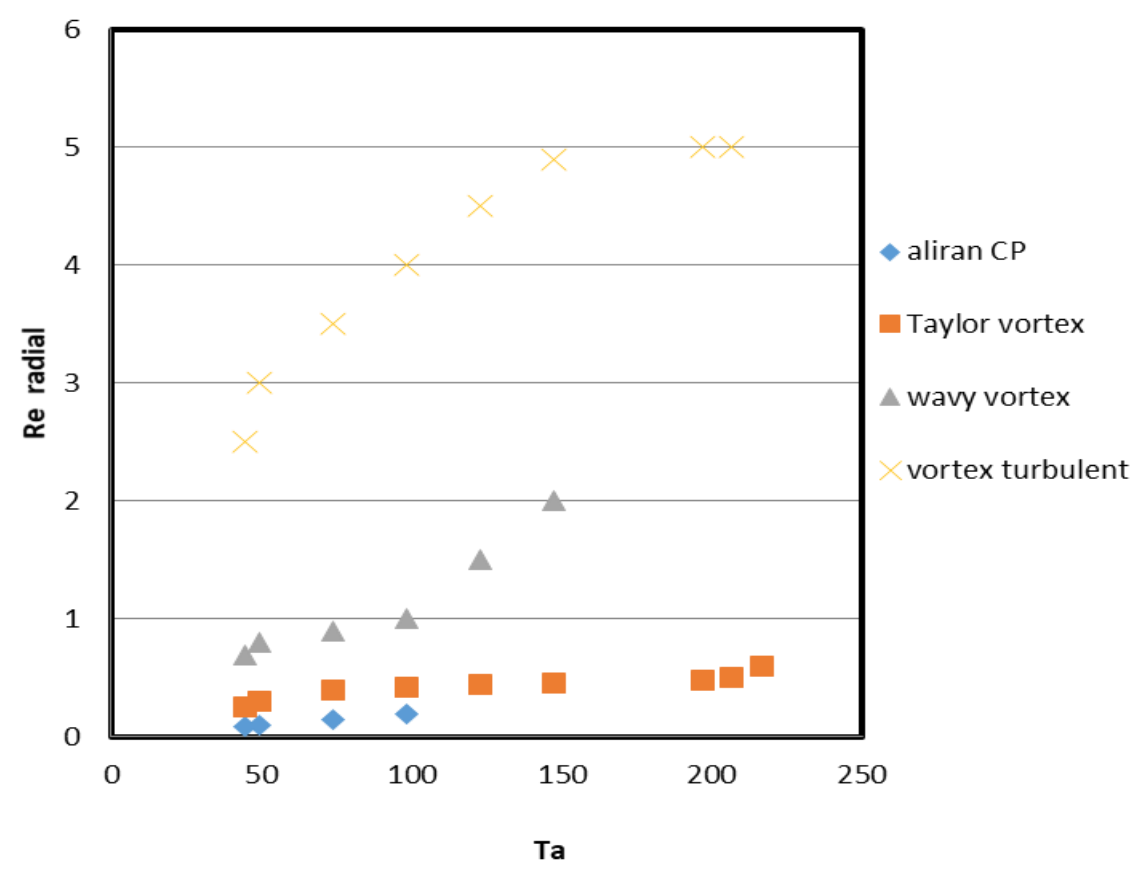

Gambar 6. Peta pola aliran Taylor-couette Poiseuille dengan silinder bagian dalam porous 1 mikron pada bilangan $\mathrm{Re}_{\text {aksial }}=51,6$.

Pola aliran yang terbentuk dimulai dari bilangan Reynolds radial rendah berupa aliran couette Poiseuille atau couette laminar dengan seiring bertambahnya nilai bilangan Reynolds radialnya maka pola aliran yang terbentuk berubah menjadi Taylor vortex, wavy vortex dan vortex turbulen.

\section{Aliran aksial-radial untuk silinder bagian dalam tiga mikron}

Dalam sistem aliran Taylor-Couette Poiseuille untuk silinder bagian dalam tiga mikron dengan aliran aksial-radial telah menghasilkan fenomena pola aliran seperti pada Gambar 7.

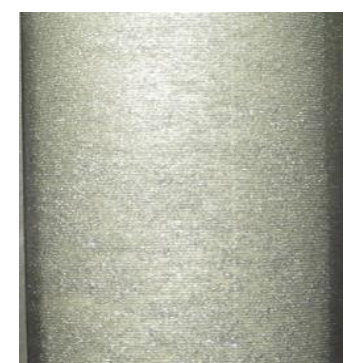

a

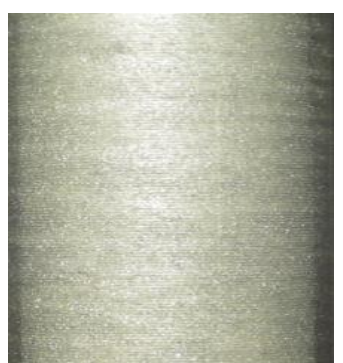

$\mathrm{b}$

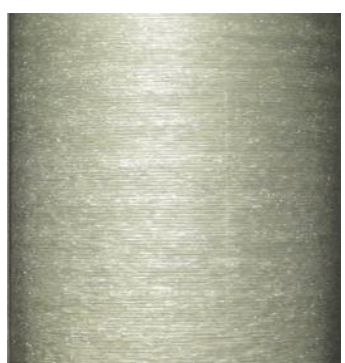

c

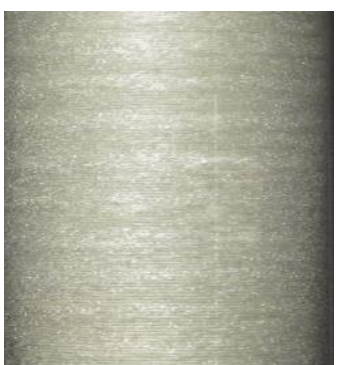

d

Gambar 7. Pola aliran Taylor-Couette dengan aliran aksial-radial untuk silinder dalam 3 mikron pada $\mathrm{Re}_{\text {aksial }}=51,6$

a. Aliran couette laminer pada $\mathrm{Re}=99, \mathrm{Re}_{\mathrm{rad}}=1,5$

b. Aliran Taylor-vortex pada $\mathrm{Re}=345, \mathrm{Re}_{\mathrm{rad}}=1,2$

c. Aliran wavy vortex pada $\operatorname{Re}=1480, \operatorname{Re}_{\mathrm{rad}}=1,4$

d. Aliran vortex turbulen pada $\mathrm{Re}=1974, \mathrm{Re}_{\mathrm{rad}}=1,5$

Dengan adanya aliran aksial-radial yang semakin besar pola aliran Taylor-couette Poiseuille yang terbentuk juga mengalami perubahan yang besar pula yang ditandai dengan meningkatnya aliran transisi terjadinya vortex pada bilangan Reynolds yang tinggi pada bilangan Taylor yang 
tinggi pula artinya stabilitas aliran Taylor-couette Poiseuille juga meningkat. Bila hasil visualisasi pola aliran tersebut dituangkan ke dalam sebuah gambar peta pola aliran seperti tampak pada Gambar 8.

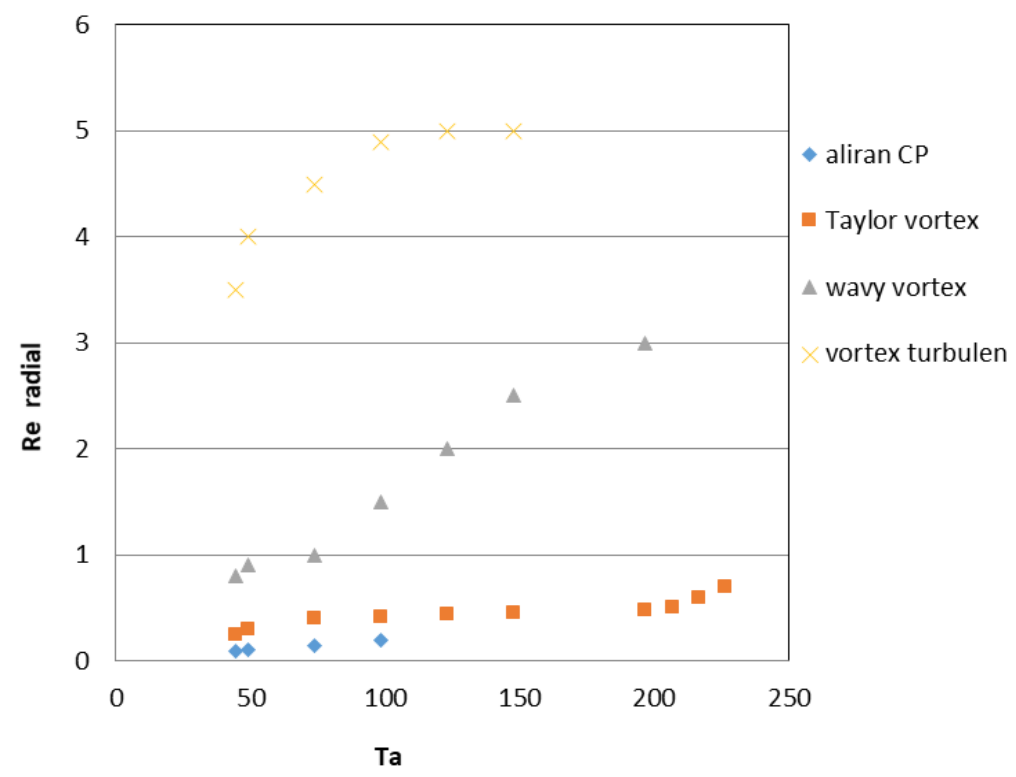

Gambar 8. Peta pola aliran Taylor-couette Poiseuille dengan silinder bagian dalam porous 3 mikron pada bilangan $\operatorname{Re}_{\text {aksial }}=51,6$.

Pola aliran yang terbentuk dimulai dari bilangan Reynolds radial rendah berupa aliran couette Poiseuille atau couette laminar dengan seiring bertambahnya nilai bilangan Reynolds radialnya maka pola aliran yang terbentuk berubah menjadi Taylor vortex, wavy vortex dan vortex turbulen.

\section{Aliran aksial-radial untuk silinder dalam lima mikron}

Aliran Taylor-Couette Poiseuille untuk silinder bagian dalam lima mikron dengan aliran aksialradial pola alirannya seperti pada Gambar 9.

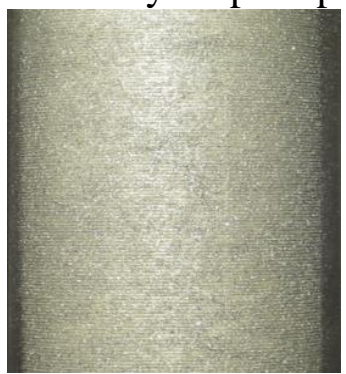

a

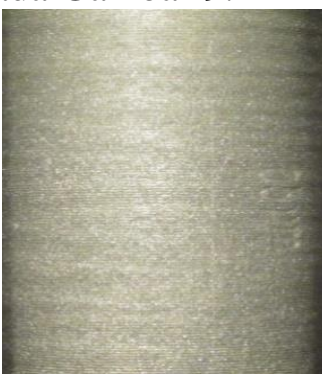

$\mathrm{b}$

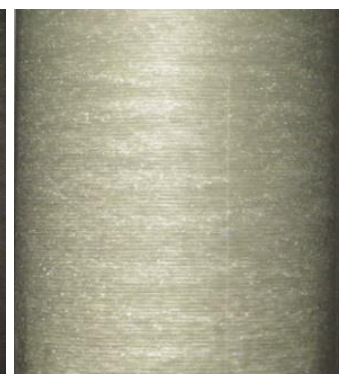

c

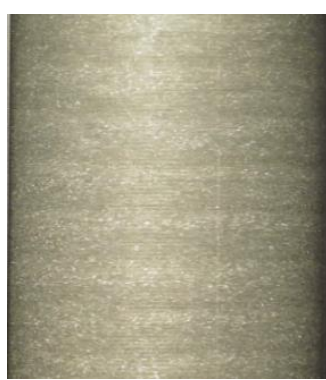

d

Gambar 9. Pola aliran Taylor-Couette dengan aliran aksial-radial untuk silinder dalam lima mikron pada $R_{\text {aksial }}=51,6$

a. Aliran couette laminer pada $\mathrm{Re}=197, \mathrm{Re}_{\mathrm{rad}}=1,5$

b. Aliran Taylor-vortex pada $\mathrm{Re}=444, \mathrm{Re}_{\mathrm{rad}}=1,2$

c. Aliran wavy vortex pada $\mathrm{Re}=1727, \mathrm{Re}_{\mathrm{rad}}=1,5$

d. Aliran vortex turbulen pada $\mathrm{Re}=2220, \mathrm{Re}_{\mathrm{rad}}=1,3$

Dengan adanya aliran aksial-radial yang semakin besar lagi pola aliran Taylor-couette Poiseuille yang terbentuk juga mengalami perubahan yang semakin besar lagi yang ditandai dengan 
transisi terjadinya vortex pada bilangan Reynolds yang semakin tinggi pula pada bilangan Taylor yang tinggi pula artinya stabilitas aliran Taylor-couette Poiseuille juga meningkat. Bila hasil visualisasi pola aliran tersebut dituangkan ke dalam sebuah gambar peta pola aliran maka posisinya tampak terlihat pada Gambar 10.

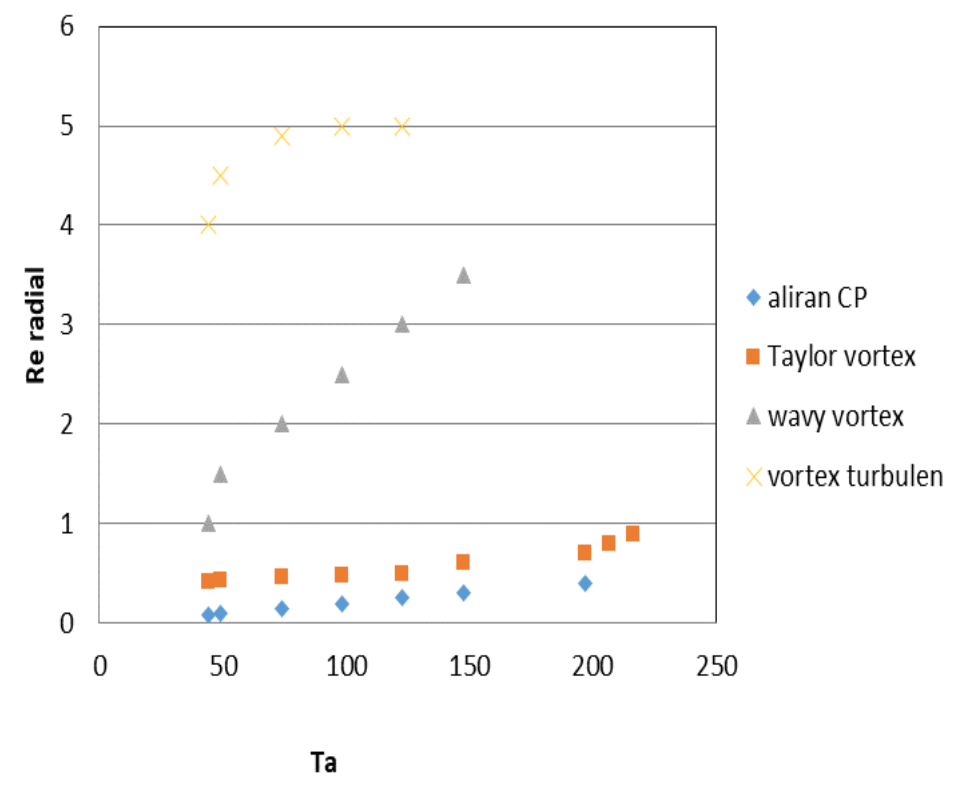

Gambar 10. Peta pola aliran Taylor-couette Poiseuille dengan silinder bagian dalam porous 5 mikron pada bilangan $\operatorname{Re}_{\text {aksial }}=51,6$.

Pola aliran yang terbentuk dimulai dari bilangan Reynolds radial rendah berupa aliran couette Poiseuille atau couette laminar dengan seiring bertambahnya nilai bilangan Reynolds radialnya maka pola aliran yang terbentuk berubah menjadi Taylor vortex, wavy vortex dan vortex turbulen.

\section{KESIMPULAN DAN SARAN}

Hasil penelitian aliran Taylor-couette Poiseuille dengan aliran aksial-radial di dalam silinder konsentris dapat disimpulkan sebagai berikut :

a. Porousitas silinder bagian dalam dapat mempengaruhi pola aliran Taylor-Couette Poiseuille yang terbentuk ditandai dengan munculnya aliran transisi terjadinya vortex meningkat pada bilangan Reynolds melingkar yang tinggi artinya stabilitas aliran Taylorcouette Poiseuille meningkat akibat aliran aksial-radial.

b. Pengaruh kecepatan putar silinder bagian dalam dapat juga mempengaruhi pola aliran Taylor-couette Poiseuille yang terbentuk secara berjenjang dimulai dari couette laminer, Taylor vortex, wavy vortex, dan vortex turbulen terjadi di sepanjang sistem aliran.

Sedangkan saran untuk penelitian tentang Aliran Taylor-couette Poiseuille dengan aliran aksial-radial dalam silinder konsentris untuk penelitian berikutnya adalah sebagai berikut:

a. Permukaan silinder bagian dalam yang digunakan harus rata atau tidak beralur.

b. Menggunakan bahan filter yang dari keramik.

c. Memilih zat sebagai fluida kerja yang sesuai untuk visualisasi pola aliran.

d. Untuk meningkatkan hasil pola aliran yang baik sebaiknya menggunakan seksi uji yang simetris. 


\section{REFERENSI}

Andereck, C.D., Liu, S.S., Swinney, H.L. 1986. Flow regime in circular Couette system with independently rotating cylinder. J. Fluid Mechanics. Vol. 164 pp. 155-183.

Leuptow, R.M., Docter, A., Min, K. 1992. Stability of axial flow in an annulus with a rotating inner cylinder. Physics Fluid A. Vol. 4 pp. 2446-2455.

Leuptow, R.M., Min, K. 1994. Circular couette flow with pressure-driven axial flow and a porous inner cylinder. Experiment in Fluids. Vol. 17 pp. 190-197.

Leuptow, R.M., Lee, S. 2004. Model Predictions and Experiments for Rotating Reverse Osmosis for Space Mission Water Reuse. Separation Science and Technology. Vol. 39, No.3, pp. 539-561.

Leuptow, R.M., Pederson, C.L. 2006. Fouling in a high pressure, high recovery rotating reverse osmosis system. Desalination. Vol.212, pp. 1-14. 